5. Кримський С. Колізії цивілізаційного вибору в посттоталітарній Україні// Філософськоантропологічні студії 2000. Європейський вектор та основні цінності української гуманітаристики. Істина. Правда. Життя. (До 70-річчя Мирослава Поповича). - К.: Стилос, 2000. - 436 с.

6. Сорочук Л. Українознавча основа фрольклорно-етнографічних записів Павла Чубинського// Тези доповідей VI Міжнародної наукової конференції «Українська культура в історичному розвитку та державотворенні». - Київ, 2009. - С. 4-5.

7. Чередниченко Д. Павло Чубинський. Монографрія- К: Альтернатива, 2005. - 374 с.

8. Чубинський Павло. Мудрість віків. Українське народознавство у творчій спадщині Павла Чубинського. У 2 кн. - Книга 1. - К., 1995. - 224 с.

9. Чубинський П. «Труды этнографическостатистической экспедиции в Западно-Русский Край», снаряженной Имперским Русским географическим обществом. Юго-западный отдел. Материалы и исследования, собранные П. П. Чубинским. - Київ,. 1-7 тт, 1872-1878 роки.

10. Шаров І. 100 видатних імен України. - К., 1999. - 503 c.

\section{References}

1. Husyev V., Dorozhzhyn V., Kalintsev Y., 2002. Vydatni postati $v$ istoriyi Ukrayiny (IX-XIX centuries: Korotki biohrafichni narysy. Istorychni ta khudozhni portrety [Outstanding figures in the history of Ukraine (IX-XIX centuries): Brief biographical essays. Historical and artistic portraits]. Kyiv: Vyshcha shkola. 360 s. (in Ukrainian).

2. Dyv. Rusova S., 2007. Iz lystiv Pavla Chubyns koho do dvoyuridnoyi sestry - Oleksandry Kistyakivs koyi [From the letters of Pavlo Chubyns'kyy to the cousin - Oleksandra Kistyakovska] // Dyzayn-osvita, - № 8-10. (in Ukrainian).

3. Zyl' A., 2009. Narodoznavets'. Pavlo Chubyns'kyy i yoho doba [People's connoisseur. Pavlo Chubyns'kyy and his period] . Kyiv: TOV «Kazka».(II) 395 s. (in Ukrainian).

4. Kanak F., 2000. Elity v hromads komu suspil stvi [ Elite in public society]. Article //
Philosophical and anthropological studios 2000. European vector and the main values of Ukrainian humanities. - Realness. Truth. Life. (Do 70-richchya Myroslava Popovycha). Kyiv: Stylos. 436 s. (in Ukrainian).

5. Kryms kyy S., 2000. Koliziyi tsyvilizatsiynoho vyboru $v$ posttotalitarniy Ukrayin [Conflicts of civilization choice hjct-coionial in Ukrainiani]. Article // Filosofs ko-antropolohichni studiyi 2000. Yevropeys kyy vektor ta osnovni tsinnosti ukrayins koyi humanitarystyky. - Istyna. Pravda. Zhyttya. (Do 70-richchya Myroslava Popovycha). Kyiv: Stylos. 436 s. (in Ukrainian).

6. Sorochuk L., 2009. Ukrayinoznavcha osnova fol'klorno-etnohrafichnykh zapysiv Pavla Chubyns'koho [Ukrainian-based foundation of folklore and ethnographic records by Pavlo Chubyns'kyy]. Tezy dopovidey VI Mizhnarodnoyi naukovoyi konferentsiyi «Ukrayins'ka kul'tura v istorychnomu rozvytku ta derzhavotvorenni». Kyiv, 2009. S. 4-5 (in Ukrainian).

7. Cherednychenko D., 2005. Pavlo Chubyns kyy: monograph [Pavlo Chubyns kyy: monograph]. Kyiv: Al ternative. 376 s. (in Ukrainian).

8. Chubyns kyy Pavlo, 1995. Mudrist vikiv. Ukrayins ke narodoznavstvo u tvorchiy spadshchyni Pavla Chubyns koho. u $2 \mathrm{kn}$. [Wisdom of the ages. Ukrainian folklore in the creative heritage of Pavlo Chubyns'kyy]. Knyha 1. Kyivю. 224 s. (in Ukrainian).

9. Chubyns kyy P. «Trudy etnograficheskostatisticheskoy ekspeditsii v Zapadno-Russkiy Kray», snaryazhennoy Imperskim Russkim geograficheskim obshchestvom. Yugo-zapadnyy otdel. Materialy i issledovaniya, sobrannyye P.P. Chubyns'kym ["Proceedings of an ethnographic-statistical expedition to the West-Russian Land", equipped with the Imperial Russian Geographical Society. South-western department. Materials and research collected by P.P. Chubyns'kyy]. Kyiv, 1-7 tt., 1872-1878. (in Russian).

10. Sharov I., 1999. 100 vydatnykh imen Ukrayiny [100 prominent names of Ukraine]. Kyiv. 503 s. (in Ukrainian).

\title{
Тетяна Трегубенко
}

\section{УКРАЇНСЬКА ЦЕРКОВНА ЕЛІТА У ФОРМУВАННІ МУЗИЧНИХ ОСЕРЕДКІВ ПРИ ДУХОВНИХ НАВЧАЛЬНИХ ЗАКЛАДАХ ГЕТЬМАНЩИНИ}

Анотація. У статті здійснено спробу з'ясувати роль української церковної еліти у фооруванні музичних осередків Гетьманщини, а також реконструювати їх кадровий склад. Відзначено, що специфікою фоормування цих музичних осередків було те, що вони зосереджувалися при тогочасних духовних навчальних закладах, які готували кадри композиторів та виконавців. Провідним з них була Києво-Могилянська академія, яка упродовж тривалого часу була головною "кузнею кадрів» українських співаків, учителів співів, регентів та композиторів для всіх українських земель. Музичні осередки у Чернігові, Харкові та Переяславі зосереджувалися при колегіумах, започаткованих місцевими архієреями і повністю залежали від їх особистої зацікавленості. Зроблено висновок, що більщість єпархіальних архієреїв активно сприяли розвитку музичної освіти у своїх єпархіях, окремі з них стали засновниками хорових колективів та авторами музичних творів. Чернігівський осередок, започаткований архієпископом Лазаром 
Барановичем більш ніж на півстоліття раніше від Харківського та Переяславського, мав перевагу завдяки діяльності власної друкарні, яка друкувала різні музичні твори, чим забезпечувала поступ музичного мистецтва на Чернігівщині і всій Лівобережній Україні.

Ключові слова: українська церковна еліта, музичні осередки, Гетьманщина, Києво-Могилянська академія, колегіуми, архієреї.

\section{Tregubenko Tetiana}

\section{UKRAINIAN CHURCH ELITE IN FORMATION OF MUSICAL CENTERS UNDER SPIRITUAL EDUCATIONAL INSTITUTIONS OF HETMANATE}

Abstract. For a long time, the creative heritage of many singers and composers of the seventeenth and eighteenth centuries, which was created at Hetman residences, churches and monasteries remained insufficiently explored, and partly unknown. In recent decades a number of works by domestic musicologists have been published, which largely filled this gap. Works mainly concern secular music or some of the most well-known composers who wrote spiritual music. At the same time, the scope of the activities of the church musical centers remains unexplored to modern days, as are the names of many of their representatives from the monastic structure.

In this article was made the attempt to find out the role of the Ukrainian church elite in formation of the musical centers of Hetmanate, as well as to reconstruct their personnel on the basis of the analysis of newly discovered archival documents and various publications. It was noted that the specifics of the formation of these musical centers was that they focused on contemporary spiritual educational institutions that were preparing the frames of composers and performers. The leading of them was the Kyiv-Mohyla Academy, which for a long period of time was the main "staff of personnel" of the time composers of spiritual music and performers of choral church singing. The organizers of the musical life at the Academy were first of all its rectors, who opened the music classes, organized student choirs and wrote musical works for them. A separate subject, which was studied at the Academy, was Kant's singing, the formation of which was facilitated by the new Paretza system of choral performance.

Musical centers in Chernihiv, Kharkiv and Pereyaslav focused on collegiums initiated by local bishops and completely dependent on their personal interest. It is concluded that the majority of diocesan bishops actively promoted the development of musical education in their eparchies, some of them became founders of choral groups and authors of musical works. The Chernihiv cell, initiated by Archbishop Lazar Baranovich more than half a century earlier from Kharkiv and Pereyaslavsky, benefited from the activity of his own printing press, which published various musical works, which ensured the progress of musical art in Chernihiv region and the entire Left Bank Ukraine.

Key words: Ukrainian church elite, Musical centers, Hetmanate, Kyiv-Mohyla Academy, Collegiums, Bishops.

Протягом тривалого часу творча спадщина багатьох співаків і композиторів XVII-XVIII ст, що творили при гетьманських резиденціях, церквах та монастирях, залишалася недостатньо дослідженою, а почасти й невідомою. В останні десятиліття вийшла низка праць вітчизняних музикознавців, які значною мірою заповнили цю прогалину. Зокрема, ґрунтовними у цьому зв'язку є праці Н. ГерасимовоїПерсидської, М. Боровик, М. Антоновича, Л. Корній., П. Козицького, Я. Ісаєвича. Проте вищеназвані праці переважно стосуються саме світської музики або окремих, найбільш відомих композиторів, які писали духовну музику. Водночас сфера діяльності церковних музичних осередків до сьогоднішнього часу залишається невивченою, як й імена багатьох їх представників з чернечого складу.

У даній статті на основі аналізу нововіднайдених архівних документів та різного роду публікацій зроблено спробу з'ясувати роль української церковної еліти у формуванні музичних осередків Гетьманщини, а також реконструювати їх кадровий склад. Мова буде йде передусім про музичні центри при навчальних закладах: у Києві - при КиєвоМогилянській академії (при Києво-Братському монастирі), а також у Чернігові, Харкові та Переяславі, які зосереджувалися при резиденціях місцевих архієреїв. В цей час існували й досить потужні світські музичні осередки, які організовувала у себе для розваги українська козацька еліта, зокрема Глухівський при гетьманському дворі, але вони не $є$ предметом нашого дослідження.

Провідним із церковних музичних осередків, які зосереджувалися при тогочасних духовних навчальних закладах, була Києво-Могилянська академія. За ії зразком формувалися інші навчальні заклади - колегіуми у Чернігові, Харкові та Переяславі. Саме Академія була головною «кузнею кадрів» українських співаків, учителів співів, регентів та композиторів для всіх українських земель.

Окремим предметом, який вивчався в Академії, був кантовий спів (кант - триголосна куплетна пісня, призначена для виконання невеликим ансамблем чи навіть хором без музичного супроводу). Його становленню сприяла нова партесна система хорового виконання. На мелодії кантів часто виконувалися псалми. Канти, як і партесні хори, увібрали в себе характерні особливості української народної пісні.

Музика входила до програми «Семи вільних наук», хоча винесена була, як і малювання, в клас неординарний. Як зазначалося в «Євхаристиріоні» (1632) - панегірику, який студенти Лаврської школи присвятили своєму покровителеві архімандриту Петру Могилі, музика це не лише «сад утіхи й веселощів», а й творча сила, що прикрашає слово, надихає душу й серце на «мислі вдячні», $€$ їх життєдайним джерелом [9, с. 105]. 
Організаторами музичного життя в Академії були насамперед її ректори. Так, першого ректора Академії Іова Борецького кияни шанували й називали «другим Іоаном Милостивим». Він втілював у життя думку про те, що спів і музика є важливими важелями естетичного виховання, та доклав чимало зусиль, щоб навчити учнів і півчих правильному церковному співові, викорінювати так звану хомонію розтягування слів за рахунок додавання до них голосних на шкоду мелодії [5, с. 80].

Любив і пропагував музику і ректор Академії Лазар Баранович. За часів його керівництва Академією у середині XVII ст. в Академії було організовано студентський хор, згодом відкрито клас нотного співу та інструментальної музики. Баранович сам писав музику - псалми й канти, зокрема в одному з рукописних Ірмологіонів (після 1700 р.) вміщено його «Херувимську» (зберігається у Львівському історичному музеї) [5, с. 60].

Ректор Іриней Фальковський надав кошти на відкриття нотного класу, який перед тим певний час не фрункціонував. Він особисто був автором музичних творів, переважно псалмів і гімнів [5, с. 557-559].

Документи стверджують, що з вихованців КиєвоМогилянської академії з відповідними вокальними даними поповнювався склад митрополичого хору при Київській архієрейській кафедрі. Про це, зокрема, свідчить прохання учнів нижчих класів Академії Івана Злотковського, Григорія Яновського і Федора Ревуцького, датованого 1749 р., про призначення їм нового інспектора [1, с. 394-396]. Вони навчалися в Академії, проживали у Києво-Софійському монастирі й водночас співали у митрополичому хорі.

Музичне виховання було органічною частиною академічного життя. Хор Академії налічував іноді 300 і більше співаків. Він незмінно залишався кращим під час змагання усіх київських хорів, які щороку відбувалися в Києві на Контрактовій площі. Без участі студентського хору і оркестру не обходилися різні урочистості і традиційні травневі студентські рекреації - вільні від занять дні відпочинку і літні гуляння.

Академія, як основний центр підготовки музичних кадрів, дала світові таких музичних світочів, як М.Березовський, Д. Бортнянський та А.Ведель.

Крім Києво-Могилянської академії важливу роль у розвитку українського церковного музичного мистецтва відігравали колегіуми у Чернігові, Харкові та Переяславі, при яких започатковувалися осередки хорового співу. Їх розвиток значною мірою залежав від особистих зацікавлень у цій сфері місцевих архієреїв, які були засновниками і покровителями єпархіальних навчальних закладів, створених на базі архієрейських резиденцій.

Так, архієпископ Чернігівський і НовгородСіверський Лазар Баранович (1657 - 1693), поет і письменник, як йшлося вище, особисто любив музику і ще в київський період своєї діяльності створив при Київському Братському монастирі церковний хор і хорову школу. У своєму архієрейському осідку в
Чернігові Лазар Баранович також започаткував хорову капелу, якою керував С. Пекалицький, і утримував її власним коштом. Баранович особисто писав музичні твори, зокрема "П'ять нот» (1680). $€$ також відомості про поширення створених ним кантів і псалмів [5, с. 59-60].

Наступник Лазаря Барановича Чернігівський архієпископ Іоанн Максимович також опікувався розвитком музичного осередку при Чернігівському архієрейському домі. Новий етап цим процесам надало започаткування ним Чернігівського колегіуму у 1700 р., де учні навчалися також музичної грамоти. Як пише О. Васюта, там «велося викладання музики, був хор, оркестр» [2, с. 163].

Подібно до системи, що діяла в КиєвоМогилянській Академії, у Чернігівському колегіумі значна увага приділялася музичному вихованню. Музика включалася також в українську шкільну драму. Відомо, що вже на початку існування Чернігівського колегіуму в ньому, як і в Києво-Могилянській академії, складалися та ставилися п'єси. Автором драматичних творів, як правило, був учитель курсу поетики. «Спудеї» Чернігівського колегіуму часто виступали з п'єсами як на громадських, так і на релігійних святах. Цьому сприяли і самі чернігівські архіпастирі. Так, ще на ранній стадії діяльності колегіуму архієпископ Антоній Стаховський дозволив бідним учням «миркования и спевание» - «пение духовых песен» [7, с. 73].

Відомо також, що Димитрій Туптало - майбутній митрополит Ростовський і Ярославський - за час перебування в Чернігівському культурнопросвітницькому осередку написав низку поетичних кантів, які пізніше увійшли до антології духовної пісні «Богогласник», що засвідчує їх велику популярність $[13$, с. 49].

Про кадровий склад Чернігівського музичного осередку у XVIII ст. існують лише окремі згадки в літературі. Так, історико-статистичний опис Чернігівської єпархії свідчить, що у 1737 р. при Чернігівській кафедрі було 15 півчих [4, с. 103-104].

Певні дані про окремих чернігівських співаків та музикантів цього часу подає дослідник українських впливів на російську культуру К. Харлампович. Він, зокрема, зазначає, що Чернігівський архієпископ Іоанн Максимович 1703 р. під час поїздки в Москву взяв з собою регента Івана з 4-ма півчими, а отримавши в 1711 р. переміщення на Тобольську митрополичу кафедру, взяв 3 собою 4 співаків 3 Чернігова: баса Федора, тенора Дем'яна, альтів Андрія та Василя. Його наступник і на Чернігівській, i на Тобольській кафедрі Антоній Стаховський за свої власні кошти також викликав співаків з Чернігова [8, С. $822,824,835-836]$.

Вихованцями Чернігівського колегіуму були відомі співаки і композитори. Так, близько 1737-41 років тут навчався Марко Полторацький, учитель М. Березовського і Д. Бортнянського, перший російський оперний співак, який 1763 р. став директором придворної співочої капели в Росії, а згодом 
зарахований до придворної італійської опери, яка була загально-визнаним мистецьким еталоном того часу [5, с. 436-437].

Варто зазначити, що започаткований архієпископом Лазаром Барановичем Чернігівський осередок мав перевагу завдяки діяльності власної архієрейської друкарні, яка друкувала різні музичні твори, чим забезпечувала поступ музичного мистецтва на Чернігівщині і всій Лівобережній Україні.

Церковний музичний осередок Слобожанщини гуртувався при Харківському Покровському монастирі, де 31726 р. став діяти колегіум, започаткований єпископом Єпифанієм Тихорським (1722-1731) на основі Бєлгородської архієрейської школи. 3 початком діяльності навчального закладу з'явився перший церковний хор з учнів колегіуму, яким керував особисто засновник колегіуму. Співав цей хор виключно в Покровській колегіумській церкві. Згадок про нього збереглося небагато, але наскільки він був професійним, можна судити з того, що його півчих, учнів колегіуму, неодноразово викликали в столичні міста Російської держави для придворної хорової капели та монастирських хорів. Так, 1738 р. указом Св. Синоду «для содержанія кіевскаго пенія» в Московському Донському монастирі було викликано регента Бєлгородського архієрейського дому Андрія, у чернецтві Арсенія [8, с. 837]. За даними архівного фонду Харківського колегіуму, який $€$ особливо цінним в дослідженні питання кадрового складу хористів, згідно 3 указом Бєлгородської духовної консисторії у 1747 р. керівництво колегіуму відправило до Санкт-Петербурга двох учнів-співаків - Петра Кожинського і Федора Андрієвського [12, арк. 1-3].

Провідний навчальний заклад Слобожанщини постійно перебував у центрі особливої уваги бєлгородських преосвященних. Крім засновника колегіуму Єпифанія Тихорського велику увагу розвитку хорового співу в Харкові надавав Бєлгородський єпископ Аггей Колосовський (17741786). Своїми указами він намагався віднайти у своїй єпархії для архієрейського хору найкращі голоси. Так, його указ про набір архієрейських півчих від 16 серпня 1779 р. проливає світло на деталі цього процесу, ставлення до нього архієрея і місцевого духовенства. В указі, зокрема, значилось: «Его преосвящеииство, разсуждая что ныне в состоящей при доме архіерейском певческой капелле в разных голосах немалый находится недостаток, определил: избрав способных к тому и знающих совершенно доброту и различіе голосов из священников или приичетников отправить в разные по росписанію тракты с инструкціями, коим, по прибытіи в каждое духовное правленіе, истребовав от духовных правленій о священно церковно-служительских детях с показаніем лет без всякой утайки ведомости, отправиться по оным селеніям и самолично таковых священно и церковно-служительских детей осмотреть и в голосах каждаго испробовать» [6, с. $212-213]$.
За аналогією 3 Харківським та Чернігівським культурно-просвітнцькими осередками церковне музичне життя Переяслава зосереджувалося при архієрейській резиденції - в Переяславському Борисоглібському монастирі. Навчання музичній грамоті відбувалося в заснованому єпископом Арсенієм Берлом 1737 р. Переяславському колегіумі. Відомо, що нотному співу в Переяславській семінарії починали навчати з класу синтаксими [3, с. 748].

На відміну від інших, Переяславський церковний музичний осередок був, очевидно, менш потужний: по-перше, тут значно пізніше відкрився колегіум, який готував музичні кадри; по-друге, відсутність власної друкарні не давала достатньої можливості забезпечувати хористів необхідною музичною літературою.

Проте досить успішне функціонування осередку засвідчують віднайдені нами матеріали, які дають можливість реконструювати і його кадровий склад. Так, Ілля Турчиновський, який походив 3 сім'ї козацької старшини м-ка Березані, навчався у КиєвоМогилянській академії, співав на крилосі КиєвоМихайлівського монастиря, а з 1710 р. пішов у мандри по Україні та Білорусії, де в тому числі вдосконалював і свої музичні задатки. Близько 17161717 рр. він у супроводі співака Івана Мазуровича повернувся в Березань, де був «принят в певчіе в катедру переяславскую к Кирилу Шумлянскому за регента». 3 листопада 1718 р. у Березанській СвятоУспенській церкві за «певческие заслуги» йому дали місце священика [5, с. 549-550].

Відомий дослідник українських церковних впливів на Росію К. Харлампович, подаючи переліки українців, які у XVII - XVIII ст. перебували в Росії, під 1727 р. згадує співака цариці Катерини Олексіївни Леонтія Ливчинського, який жив раніше у переяславського єпископа Кирила Шумлянського. Звідси також дізнаємося, що Переяславський єпископ Іоаким Струков, переміщений в 1730 р. у Вороніж, взяв з собою співака та бандуриста, проте їхніх прізвищ не наводить [8, с. 822, 837].

Зберігся указ Переяславського єпископа Гервасія Лінцевського 1758 р., яким він зобов'язував місцевих священиків готувати своїх дітей до вступу в семінарію - навчати їх грамоті і церковному співу [3, c. 743].

Рапорти духовних правлінь за 1780 р. також свідчать про активні пошуки співаків для єпископського хору. Такі відомості надало, зокрема, Шаргородське духовне правління від 18 вересня 1780 р., надіславши Переяславській духовній консисторії відомості про осіб, яких мали направити в якості хористів [10]. 3 іншої справи під тим самим роком дізнаємося про відправлення двох співаків Переяславського єпархіального хору Андрія Максимовича і Данила Пономаревського в розпорядження Новгородського и Санкт-Петербурзького єпископа Гавриїла [11, арк. 1].

Така кількість архівних документів під 1780 роком засвідчує, що тогочасний єпископ 
Переяславский і Бориспільський Іларіон Кондратковський (1776 - 1785) виявляв особливу турботу про розвиток хорового співу у своїй резиденції. За часи його правління діяльність Переяславського музичного осередку особливо активізується.

Отже, українська церковна еліта відіграла значну роль у становленні українських церковних музичних осередків, які переважно зосереджувалися при тогочасних духовних навчальних закладах. Провідним з них була Києво-Могилянська академія, яка упродовж тривалого часу була головною «кузнею кадрів» українських співаків, учителів співів, регентів та композиторів для всіх українських земель. Більшість єпархіальних архієреїв активно сприяли розвитку музичної освіти у своїх єпархіях, окремі 3 них стали засновниками хорових колективів та авторами музичних творів. Чернігівський осередок, започаткований архієпископом Лазаром Барановичем більш ніж на півстоліття раніше від Харківського та Переяславського, мав перевагу завдяки діяльності власної друкарні, яка друкувала різні музичні твори, чим забезпечувала поступ музичного мистецтва на Чернігівщині і всій Лівобережній Україні.

1. Акты и документы, относящиеся к Киевской Академии. - Отд. II / Под ред. Н.И. Петрова. - Т. 1, ч.1. К., 1904. -463 c.

2. Васюта О. Музичне життя на Чернігівщині у XVIII - XIX ст.: історико-культурологічне дослідження / О. Васюта. - Чернігів: РВК «Деснянська правда», 1997. 212 c.

3. Демидовский В. Краткий очерк состояния Переяславско-Полтавской Семинарии со времени основания ее (1738 г.) до преобразования в 1817 г. / В. Демидовский // Полтавские епархиальные ведомости. 1888. - Часть неоффициальная. - С. 735-776.

4. Историко-статистическое описание Черниговской епархии. -Кн. 4. - Чернигов, 1873. - 392 с.

5. Києво-Могилянська академія в іменах: Енциклопедичне видання / Упоряд. 3.І.Хижняк; За ред. В.С. Брюховецького. - К.: Вид. дім «КМ Академія», 2001.- $733 \mathrm{c}$.

6. Лебедев А.С. Белгородские архиереи и середа их архипастырской деятельности /А.С. Лебедев. Харьков, 1902. - 288 с.

7. Травкіна О.І. Чернігівський колегіум / О.І. Травкіна // Український історичний журнал. - 2000. - №5. - C. 68-78.

8. Харлампович К. В. Малороссийское влияние на великорусскую церковную жизнь / К.В. Харлампович. Т. 1 - Казань, 1914.- 970 с.

9. Хижняк 3.І., Маньківський В.І. Історія КиєвоМогилянської академії / 3.І. Хижняк, В.І.Маньківський. К.: КМ Академія, 2003. - $181 \mathrm{c.}$

10. ЦДІАК України, фр. 990, оп.1, спр. 1450.

11. ЦДІАК України, ф. 990, оп.1, спр. 1451.

12. ЦДІАК України, ф. 1973, оп. 1, спр. 49, арк. 1-3.

13. Шевчук В. Співці музи роксоланської в Чернігові. Києво-чернігівський осередок поетів другої половини
XVII та першої половини XVIII століття / Валерій Шевчук // Чернігівські Афріни / упорядкування, передмова А. Макарова. - К.: «Мистецтво», 2002. - С. 126-134.

\section{References}

1. Akty i dokumenty, otnosyashchiyesya k Kiyevskoy Akademii (1904). Collection of documents. Otd. II / Pod red. N.I. Petrova. T. 1, ch.1. Kiev. 463 p. (in Russian).

2. VASYUTA, O. (1997). Muzychne zhyttya na Chernihivshchyni u XVIII - XIX st.: istorykokul turolohichne doslidzhennya [Musical life in Chernigiv region in the XVIII - XIX centuries: historical and cultural research]. Monography. Chernihiv. RVK «Desnyans ka pravda». 212 p. (in Ukrainian).

3. DEMIDOVSKIY, V. (1888). Kratkiy ocherk sostoyaniya Pereyaslavsko-Poltavskoy Seminarii so vremeni osnovaniya yeye (1738 g.) do preobrazovaniya $v$ 1817 g. [A short essay on the state of the PereyaslavPoltava Seminary since its foundation (1738) before the transformation in 1817] Article // Poltavskiye yeparkhial'nyye vedomosti. Chast' neoffitsial'naya. S. 735776 (in Russian).

4. Istoriko-statisticheskoye opisaniye Chernigovskoy yeparkhii [Historical and statistical description of the Chernigov diocese]. (1873). Directory. Kn. 4. Chernigov. 392 p. (in Russian).

5. Kyyevo-Mohylyans ka akademiya $v$ imenakh [Kyiv-Mohyla Academy in names: Encyclopedia edition]. Entsyklopedychne vydannya. Uporyad. Z.I.Khyzhnyak. Za red. V.S. Bryukhovets koho (2001). Kyiv. Vyd. dim «KM Akademiya».733 p. (in Ukrainian).

6. LEBEDEV, A.S. 1902. Belgorodskiye arkhiyerei i sreda ikh arkhipastyrskoy deyatel'nosti [Belgorod bishops and the middle of their archpastoral activity]. Monography. Khar'kov. 288 p. (in Russian).

7. TRAVKINA, O. (2000). Chernihivs kyy kolehium [Chernihiv Collegium]. Article // Ukrayins kyy istorychnyy zhurnal. №5. S. 68-78 (in Ukrainian).

8. HARLAMPOVICH, K.V. (1914). Malorossijskoe vlijanie na velikorusskuju cerkovnuju zhizn [Little Russian influence on the Great Russian church life]. Monography. T. 1. Kazan. 970 p. (in Russian).

9. KHYZHNYAK, Z., MAN KIVS KYY, V. (2003). Istoriya Kyyevo-Mohylyans koyi akademiyi [History of the Kyiv-Mohyla Academy]. Teaching manual. Kyiv. 181 p. (in Ukrainian).

10. Centralnyi derzhavnyj istorychnyj arhiv Ukrainy, Kyiv (CDIAK Ukrainy). Fond 990. Opys 1. Sprava 1450.

11. CDIAK Ukrainy. Fond. 990. Opys 1. Sprava 1451.

12. CDIAK Ukrainy. Fond 1973. Opys 1. Sprava. 49. Ark. 1-3.

13. SHEVCHUK, V. (2002). Spivtsi muzy roksolans koyi $v$ Chernihovi. Kyyevo-chernihivs kyy oseredok poetiv druhoyi polovyny XVII ta pershoyi polovyny XVIII stolittya [Collaboration of the Roxolan music in Chernigov. Kyiv-Chernihiv cell of poets of the second half of the XVII and the first half of the XVIII century]. Article. Chernihivs ki Afiny. Uporyadkuvannya, peredmova A. Makarova. Kyiv. «Mystetstvo». S. 126-134 (in Ukrainian). 